\title{
The Gülen Movement: Between Turkey and International Exile
}

\author{
Caroline Tee
}

\section{1 Introduction}

Since a failed attempt at a military coup on the night of 15 July 2016 , the Gülen Movement (henceforth GM), which developed around the figure of Islamic preacher and social critic Fethullah Gülen (b. 1941), has been forcibly exiled from its homeland of Turkey. ${ }^{1}$ The events of that night marked the final, explosive stage in Fethullah Gülen's transition from powerful establishment ally to Turkey's most wanted criminal (Esen and Gumuscu 2017; Yavuz and Balcı 2018; Zarakol 2016). The Turkish government holds Gülen directly responsible for masterminding the coup and the GM is referred to in Turkey today as FETö (Fethullahist Terrorist Organisation), and the unprecedented wave of arrests and state sector purges that have been witnessed since 2016 have ostensibly been aimed at its members. In reality, tens of thousands of people-many of whom have no connection to Gülen whatsoever-have lost their jobs, fled the country or are now languishing in prison. Those Gülenists who were able to escape have sought refuge overseas, many of them apparently in Western Europe and the United States of America (US), where the GM has an established presence. With its considerable financial assets in Turkey confiscated by the state, febrile anti-Gülenism pervading the public mood and President Erdoğan's grip on power consolidated through an executive presidency, there is little prospect of the GM ever recovering its once powerful position in its homeland.

Since 2016, the organisational contours of the GM have changed. Gülen continues to reside on his reclusive compound in Pennsylvania, US, where he has lived since 1999, and the efforts of the Turkish government to secure his extradition to face charges for masterminding the coup have so far failed. However, while Gülen and his inner circle of followers remain intact, the rest of the global GM has experienced serious rupture. Searching for a future outside Turkey, the

1 Some parts of this chapter have previously been published in the author's monograph, The Gülen Movement in Turkey: The Politics of Islam and Modernity (London: I.B. Tauris, 2016). 
GM has begun to regroup in nations including Germany, Sweden, the United Kingdom, and the US, where for various reasons it is finding a relatively sympathetic reception (Lesage 2019; Watmough and Öztürk 2018).

The victimisation of the GM by a now-authoritarian regime in Turkey is ironic, for it is widely recognised that between the late 1990s and early 2010 s the movement was itself one of the foremost architects of that regime. There are numerous examples during that time of Gülenist involvement in political manoeuvring; what Simon Watmough and Ahmet Öztürk (2018) have referred to in the GM context as "parapolitics." In the first two terms of the Justice and Development Party better known as the AK Parti (or AKP), founded by the current President Recep Tayyip Erdoğan, the GM acted as an unofficial ally to the government, sharing its conservative religious outlook and its desire to downgrade the power of the Kemalist establishment responsible for the construction of the modern Turkish state from its Ottoman past (Taş 2017; Yavuz 2018). Although not openly engaged in party politics, Gülen nonetheless steered a political course for the AKP by mobilising his followers in the police service and the judiciary to conspire against senior secularist figures. The so-called Ergenekon, Balyoz and Poyrazköy trials saw 275 high ranking military officers, journalists, and opposition politicians imprisoned on trumped up charges, and replaced with government sympathisers. They were subsequently exonerated and released, but the damage to Turkey's secular institutional structure had already been done. Later on, the GM would turn its political manoeuvring against its former ally, most notably —although ultimately unsuccessfullywith corruption allegations against the Prime Minister launched in December 2013. Therefore, although the coup attempt in July 2016 was the first time the GM had been accused of violence (on the public record, Gülen is a pacifist), its track record of political meddling had already been common knowledge in Turkey for many years.

While the GM has always attracted sceptics and detractors in Turkey, it has strategically recruited support for its activities overseas. It has focused particularly on centres of global power such as Washington DC. Gülen's residence in Pennsylvania has always been more than mere contingency: his followers have long been instructed to invest and settle in the US, a move that reflects the GM's global ambition and strategic vision (Hendrick 2013; Tee 2016). That vision developed pragmatically in a post-9/11 era, when the appetite for representations of 'moderate' Islam amongst western audiences and policy makers has been considerable. With its focus on secular education and inter-faith dialogue, its engagement in free market entrepreneurship, and its public support for political democracy, the GM has provided an attractive foil to the violent jihadi extremism emerging from other parts of the Muslim Middle East. 
International endorsements of the GM were especially common during its heyday, between 2002-2012, when optimism about the Turkey's future under the AKP government was high. Turkey was ascribed then with the potential to serve as a 'model' of Islam successfully co-existing with modern, liberal democracy. The GM played an important part in the construction of that image. Academics were amongst those openly expressing their admiration and support for Gülen (Ebaugh 20o9; Pandya and Gallagher 2012; Weller and Yllmaz 2012), and a body of largely uncritical pro-GM literature emerged, some of which was written and published by the GM itself from its publishing houses in New Jersey, US. More recently, and particularly since 2016, scholarship on the GM has taken a notably more critical turn. Currently, there are perhaps two major topics that occupy scholarly attention on the GM: the first of these concerns the contradictions between the GM's public image and international presence, and its 'parapolitical' activities in Turkey (Watmough and Öztürk, 2018), which-having been ignored by supporters for decades-are now beyond question; the second concerns the movement's future as a diaspora movement in the wake of 2016.

The aim of this chapter is to offer an introductory overview of the ideas, organisational structure and activities of the $\mathrm{GM}$, an explanation for its emergence and rapid rise to power and influence in late twentieth and early twentyfirst century Turkey, and an analysis of the souring of its relationship with the AKP and its dramatic fall from grace. It will conclude with a brief analysis of the current state of the field in GM studies in light of the failed coup, and the new directions that the GM now faces as a movement seeking to regroup in exile.

Fethullah Gülen was born in the village of Korucuk, Erzurum in 1938 (Mercan 2008: 34-35). His origins in Erzurum help to explain his distinctive interpretation of Islam and the Turkish nationalist tenor of the GM (Yavuz 2013: 25-46). Erzurum is a socially conservative province known for its pious population, located high on the central Anatolian plateau, within a few hours' drive of Turkey's eastern frontiers with Iran, Armenia, and Georgia. Erzurum is therefore a strategic city and has a long military history, dictated in large part by its frontier position in both Ottoman and Republican eras. Military skirmishes with neighbouring powers have been a feature of life in Erzurum for centuries and have contributed to the development of a regional identity built on strong national as well as Muslim religious sentiment. 
Typical of the time and place in which he was born, Gülen's childhood in the 1940s and 1950s was characterised by rural, Turkish Sunnī Muslim practices and ways of learning. He attended the first four years of primary school, but thereafter had a traditional religious education in local Șūfi tekkes. In the tekkes, Gülen received religious instruction from shaykhs of the Naqshbandī Order (Weismann 2007), of which his father was a member, as well as from the Qādirī Order. On leaving the tekke, Gülen continued to pursue his study of Șüfism under the guidance of various local shaykhs in Erzurum, where he also embarked on the formal study of Islamic jurisprudence ( figh).

While he was still a young man, Gülen became familiar with the teachings of Said Nursi, the Kurdish-Turkish Islamic thinker whose intellectual tradition he went on to follow (Abu Rabi 2003; Mardin 1989; Vahide 2005). Nursi (1877-1960) was a paradigmatic Turkish modernist thinker who authored the Risale-i Nur (Epistle of Light). The principle tenet of Nursi's teachings is his vision of a revitalisation of Turkish religious culture, which he saw to be under threat from the rise of scientific scepticism and secularisation in the modern age (Abu Rabi 2008; Turner 2008). He envisaged this religious revival taking place, not through the medium of political activism or violent revolution, but rather through a principle that he defined as 'positive action' (müspet hareket). This principle allowed for pious believers to engage and contribute peaceably to society at large in all of its constituent parts, and through it Nursi foresaw an effective way of reintroducing Islamic mores back into the public sphere with the ultimate aim of reinstating Islam as the guiding principle of Turkish society. Nursian principles and the core intellectual themes from the Risale are clearly visible in Gülen's own published works: indeed, members of the GM have appealed to the movement's pacifist Nursi-inspired ideology, albeit to a sometimes sceptical audience, when speaking in defence of Gülen in the post-coup era. ${ }^{2}$

\subsection{Gülen in Izmir}

At the age of eighteen, Gülen passed the exam to become a state-appointed imam and was soon sent to the western coastal city of Izmir, where he assumed the directorship of a Qurānic school attached to the Kestanepazan mosque in the city centre. It was in Izmir in the late 196os that Gülen began to attract a following, and the GM had its genesis.

2 For example, see Section 3 of the parliamentary report, "UK's Relations with Turkey," available at https://publications.parliament.uk/pa/cm201617/cmselect/cmfaff/615/61502.htm, accessed 10/05/2019. 
As well as preaching regularly at the Kestanepazarı mosque, Gülen began to visit local coffee-houses to preach and his message started to reach a wider demographic than the already religiously-observant sectors of the community. By reaching out beyond the traditional catchment of pious individuals, Gülen sought to take his message of moral and spiritual reform to a broader group of listeners in the public sphere. The teachings of Said Nursi constituted the foundations of his message, but, significantly, Gülen's presentation of those teachings focused on their practical enactment in the local context of 196os Izmir. He set out to show his early audience of students, small business owners and tradespeople how religious piety might complement, rather than compromise, their professional activities and successfully be enacted in their various spheres of worldly influence.

A major factor behind Gülen's success of these early years was his charismatic oratorical style, which he continued to manifest until 2016 through the publication of his sermons online. His use of a rather archaic Turkish is quite distinctive, and he has an extremely emotional style of delivery which often results in him being overcome and crying while preaching. This tendency to display emotion, for which he is well-known, is mocked by detractors but greatly admired by his followers, amongst whom it is interpreted as a sign of sincerity and spiritual depth.

Gülen is a social activist and in some senses an entrepreneur, but primarily he is a teacher and preacher of Islam. His interpretation of the Sunnī tradition is distinctive in a number of ways. First, it is strongly influenced by the mystical conceits of Anatolian Șüfism (Saritoprak in Yavuz and Esposito 2003: 156-169). He has written four books which address Șūfi themes directly (Gülen 2011), although the same Sunfi idiom pervades all of his writings and sermons on other topics. This is an area of Gülen's work in which he diverges somewhat from the precedent set by Said Nursi. The heavy emphasis on Șūfi themes and especially on the Șüfic concept of love is particular to Gülen and not something that is developed in the same way in Nursi's Risale.

Gülen's followers point out, however, that his reliance on mystical themes and ideas in order to communicate with his readers is entirely consistent with the Turkish cultural and religious context from which he emerged. Șüfism has been a central component of the Islam practiced in Anatolia since Ottoman times, when tarikat (Arab. taríqat, 'schools') activity characterised every level 
of society for hundreds of years. The official abolition of the tarikats in the 1920 may have dramatically reduced their presence in public life, but the language and motifs of Șüfism have continued to occupy a central place in Turkish Muslim consciousness, be it through familiarity with the folk poetry of Yunus Emre or the learned wisdom of Mevlana Rumi.

It is therefore within this framework of a broadly familiar Șufi cultural tradition that Gülen communicates. Central to Șūfi thought is the concept of love; love for God and desire, ultimately, to be united with him. Love is also a central motif in Gülen's theology:

Love is the most essential element of every being, and it is the most radiant light, and it is the greatest power; able to resist and overcome all else. Love elevates every soul that absorbs it, and prepares those souls for the journey to eternity. Souls that have been able to make contact with eternity through love exert themselves to inspire in all other souls what they have derived from eternity. They dedicate their lives to this sacred duty, a duty for the sake of which they endure every kind of hardship to the very end, and just as they pronounce 'love' with their last breath, they will also breathe 'love' while being raised on the Day of Judgment.

GÜLEN 2006: 1

Through the prism of this Șufic interpretation of love, Gülen articulates his vision for the betterment of humanity. This is a key concern that underpins his social and religious teachings, and which has become gradually more expansive and ambitious over the past fifty years of his life and career. Love of God plays a crucial role in Gülen's thought, and love of others for the sake of God is also ascribed with great importance. Altruism, which is highly praised, is therefore rooted by Gülen in Islamic spirituality and defined as, "devoting oneself to the lives of others in complete forgetfulness of all concerns of one's own[;] it is self-annihilation in the interests of others" (Gülen 2004: 10).

While Gülen draws frequently on Șūfi-inspired ideas, and often references poetry from the mystical canon to elaborate his teachings, he is clear to distance himself from the organised nature of Șūfism, namely its tarikat structure. His followers are also often at pains to point out that the movement is not a Sunfi order, appealing to two points of evidence: first, the absence in the Gülen Movement of the ritual religious practice which is a central element of the Șüfi orders; and second, the lack of initiation rites or clear demarcation of membership or belonging. 
The trope of love for God and humankind in Gülenist thought provides the context for his articulation of Said Nursi's doctrine of positive action (müspet hareket). This concept provides the essential framework for Gülen's understanding of how Islamic faith might best be enacted in the modern age and is based on the moral responsibility of believers to make a positive contribution to society in the service of Islam. The ultimate aim of positive action is the restoration of religious values to modern society, which is perceived in the Nursian (and Gülenist) imaginary to be under threat from secularisation and accompanying forces hostile to religion. Unlike other modern Muslim revival ideologies, however, which have espoused political activism and even violent revolution, positive action is a peaceful, apolitical and non-confrontational endeavour. It therefore requires of believers that they contribute to the preservation of public order and stability rather than directly challenge the status quo. The principle of positive action is explained in the following terms by a movement insider in Turkey:

In every society you might find radical challenge and violent movementsin the USA, Africa, Russia, everywhere ... But, speaking about this movement, it is not anti-systemic. It is not a protest to the existing norms, authorities, state, tradition - and I am talking about every country in which it is present. In every decade of its maybe four-decade lifespan it has been non-contentious, non-violent. This is müspet hareket, in Hocaefendi's terminology. ${ }^{3}$

Scholars and commentators in the post-coup era have recognised the obvious dissonance between the $\mathrm{GM}$ 's long-time public commitment to peaceful social activism, and the allegations of its involvement in the bloody events of 15 July 2016 (Hendrick in Yavuz and Balcı 2017).

\section{The Gülen Movement}

\subsection{Defining the Gülen Movement}

The Gülen Movement defies easy categorisation, and points of comparison with other religious organisations or ideologies are hard to find. The movement itself is ambivalent about labelling itself and tends to reject the suggestion

3 Author's interview in English with a senior management figure at Gazeteciler ve Yazarlar Vakfi (Journalists and Writers Foundation) in Istanbul, March 2013. 
that it is an organised movement (hareket) at all. Insiders talk instead of the movement as Hizmet, which literally means 'service' and refers, in this usage, to the application of the abstract, philosophical concept that they say lies at the heart of Gülen's vision of a better world. The Islamic rationale for this concept is sometimes made explicit and sometimes not. Gülen's own role within the movement is also the subject of considerable ambiguity. He is presented, not as the head of an organised, hierarchical structure, but rather as an 'inspiration' to a loose network of altruistic volunteers who are united only by their commitment to universal principles of civic and humanitarian service. Insiders typically play down their connections with one another, and a common assertion is that there is no 'organic connection' (organik bağlantı), by which is meant an official tie, between them.

Joshua Hendrick has called this tendency towards opaqueness about the movement's operational structure "strategic ambiguity," and links it to its emergence in late-twentieth century Turkey when limitations were in place on public religious identities (Hendrick 2013). It has attracted scepticism amongst detractors, who find it hard to countenance the spread of institutions and initiatives all around the world which bear the hallmark of Gülen and yet recognise no central organisational structure and have no official affiliation. These sceptics have tended also to infer an Islamist agenda at the movement's core and found it unconvincing that its interests and aspirations lie purely in the realm of civil society. In this vein, in Turkey it is common for unsympathetic outsiders to use the term cemaat (religious community) to refer to the movement, in a somewhat pejorative sense. The term cemaat has connotations of subversion in that it refers to religious groups that are still legally banned under the 1925 law which forcibly closed the Sunfi tarikats. Movement insiders argue that it is an inappropriate label, partly because of its association with religious ritual activity, which is not a feature of the movement, and partly because of its closed, sectarian implications, which Gülenist actors invariably seek to play down.

The ambiguity surrounding the movement and the identities of its affiliates has lessened to some extent since the coup attempt of 2016. Movement insiders have become rather less insistent on stating publicly that the movement is not, in fact, a movement at all and have discarded some of their earlier guarded reserve on this subject. They still, however, refer to Hizmet rather than using the term Gülen Movement, which is largely an appellation used in external, English-language sources. Insiders fluent in English might talk comfortably of 'the movement' in interviews in that language, reflecting their familiarity with the growing discourse and body of literature on Gülen in the West, but in Turkish they almost always revert back to simply 'Hizmet'. 


\subsection{Growth of a Movement in Science Education}

Science focused education has been the principal activity of the GM since its inception. In the late 196os, Gülen and a burgeoning group of followers who were attracted to his teachings started to organise summer revision camps in Izmir for local high school and university students. These early camps, which were the prototype for the global network of private schools that the Gülen Movement went on to operate, were inspired by Gülen's vision for the education of a 'golden generation' (altın nesil) equally well versed in modern science as in knowledge of Islam and Islamic ethics (Agai 2002; Tee and Shankland 2014; Tee 2016).

This distinctive educational vision can be traced back to the thought of Said Nursi, who attempted in his own lifetime to establish a university teaching both the secular and the religious sciences in the eastern city of Van. This plan encountered opposition from the state and was never realised, but the philosophical seed for the conception of such a project is contained within the pages of the Risale. Gülen articulated this educational vision in the following way:

As stated by Bediüzzaman, there is an understanding of education that sees the illumination of the mind in science and knowledge, and the light of the heart in faith and virtue. This understanding, which makes the student soar in the skies of humanity with these two wings and seek God's approval through service to others, has many things to offer. It rescues science from materialism, from being a factor that is as harmful as it is beneficial from both material and spiritual perspectives, and from being a lethal weapon. Such an understanding, in Einstein's words, will not allow religion to remain crippled. Nor will it allow religion to be perceived as cut off from intelligence, life, and scientific truth and as a fanatical institution that builds walls between individuals and nations.

ÜNAL AND WILLIAMS 1999: 318

The Izmir camps were initially all-male and were characterised by a culture of strict discipline. The inculcation of Islamic ethics is a crucial component within Gülen's educational vision, and typically takes place through the lived example of Gülenist educators and their demonstration of meritorious ethical practices (Vicini 2013). In Gülenist pedagogy, the role of the teacher is twofold: the transmission of scientific knowledge is one aspect of the teaching vocation, but of equal import is the informal mentoring of students in Islamic ethics and morality. The latter endeavour is not limited to the classroom setting but extends to extra-curricular time and space where close personal relationships 
are formed between teachers and students, and-crucially—where new recruits to the GM are cultivated.

The importance of teachers in the Gülenist project cannot be overstated. These individuals are devoted followers of Gülen, who are deeply committed to their leader, their religion, and the project of hizmet (service), which is the central concept in Gülenist ideology. According to Gülen, working as a teacher in a secular school context, or indeed as an administrator in one of the GM's dialogue or media organisations, is a manifestation of religious service and carries with it the promise of reward (sevap) in the afterlife. This reformulated theology of religious duty underpins the entire GM project and explains the extraordinary hard work and commitment of the individuals employed at Gülen schools, and, to some extent, the success of the GM educational project. It is entirely possible-indeed likely — that this cohort of loyal supporters have had no knowledge of, or involvement in, the GM's political ambitions. The organisation is strictly hierarchical in structure, with chains of command stretching from Gülen down through a senior management cohort and beyond; to national, regional and local level leaders known as abis (lit. 'big brother') and ablas ('big sister') (Hendrick 2013; Watmough and Öztürk 2018). Gülen and his most senior circle of acolytes take decisions regarding national and international strategy, and those further down the chains of transmission - the rank and file of loyal GM workers-are not necessarily party to them.

\subsection{Expansion of the $\mathrm{GM}$ in Turkey}

In the 1970s, Gülen's fledgling group of followers began to establish a presence outside Izmir and opened further summer camps as well as dormitories and after-school revision centres (dershane) in other Turkish cities. In the 1980s, changing circumstances in domestic politics and their impact on Turkish society at large had an important effect on the development and growth of the young movement. Its activities expanded dramatically during this decade following the military coup of 1980 and the new constitution of 1982, events which ushered in an era of economic liberalisation under the leadership of Prime Minister Turgut Özal.

The tenor of Turkish society shifted markedly in the 1980 s and the previously hegemonic authority of the self-consciously secular state began to concede to counter-hegemonic voices, namely those speaking for Islam (Lord 2018; Mango 2004; Zurcher 2004). This followed a decade of severe unrest and social polarisation in the 1970s, during which violent clashes between right and left-wing factions were common and the loss of life had been considerable. The military coup of 1980, under the leadership of General (subsequently, President) Kenan Evren, sought to bring an end to this chaotic situation and did so by ushering in 
an intellectual doctrine called the 'Turkish-Islamic synthesis'. Conscious at the time of internal currents of leftist dissent exacerbated by the keenly-felt threat of Soviet communism on Turkey's near borders, the 'Turkish-Islamic synthesis' paved the way for Islam to re-emerge in the public sphere, and to be recognised as the key unifying feature of the Turkish nation. The size and scope of the Directorate of Religious Affairs (Diyanet Iş̧leri Başkanlığı), was increased during this period accordingly, and religious themes began to re-emerge in various areas of national life.

During this decade, therefore, followers of Gülen benefitted from new social as well as economic conditions that were highly favourable to the flourishing of their schooling project. Private 'Gülen schools' were established in cities all over Turkey during this decade, including Yamanlar Koleji in Izmir, Samanyolu Koleji in Ankara, and Fatih Koleji in Istanbul, schools which were considered the most prestigious and academically-successful until their forced closuresalong with hundreds of other Gülen schools in Turkey-in 2016.

Followers of Gülen were also active in the 1980 os in other fields. It was during this decade that they began to invest in business as well as media, interests which later represented a significant share of the movement's total financial and cultural assets. ${ }^{4}$ In the 199os, the group started to branch out overseas, primarily in the field of education but also in these other constituent areas. The first countries that the movement expanded into were the newly-independent states of Central Asia, where Gülen's followers capitalised on the emergence of new markets following the collapse of the Soviet Union in 1991 (Özdalga 2007; Turam 2003). They did so to some extent in collaboration with the Turkish state which, under the prime ministerships of Özal and later Tansu Çiller, was itself seeking to build on the cultural ties between Turkey and the Central Asian peoples and to establish itself with a diplomatic and trading presence in that part of the world. The movement grew rapidly internationally during this time, and by the end of the 199os, it had schools and business interests in approximately eighty countries around the world.

During the 1980s and 1990s, Gülen attracted support from a new generation of pious Anatolian businessmen who established themselves during this period as successful manufacturers and exporters. Known colloquially as the 'Anatolian Tigers', they emerged from religiously and socially conservative, medium-size towns such as Kayseri, Adana and Afyonkarahisar.

4 The movement's major media corporation was Feza Gazetecilik (Feza Media Group), which owned the national daily newspaper Zaman and its English-language counterpart, Today's Zaman. Işık Sigorta was an insurance firm run by movement affiliates, and the Islamic lender Bank Asya was a Gülenist institution. All of these ventures are now closed. 
These pious entrepreneurs successfully capitalised on newly liberal conditions instigated after the 1980 coup and joined a Turkish economic elite that had previously been largely off-limits to religiously-minded people in the Anatolian hinterland.

This new phenomenon in Turkish business and industry was, in turn, institutionalised. In 1971, TÜSIAD (Turkish Industrialists' and Businessmen's Association), a staunchly secularist business confederation dedicated to the principles of Kemalism, had been established by members of Turkey's old industrial class. In 1990, MÜsIAD (Independent Industrialists' and Businessmen's Association) was founded by a new group of pious Turkish businessmen. It served as a religiously-minded alternative to TÜsIAD and has focused particularly on cultivating closer trade links with the Muslim countries of the Persian Gulf and the wider Middle East. Industrialists who were followers of Gülen later established their own Gülenist collective known as TUSKON (Confederation of Businessmen and Industrialists in Turkey) in 2005. The Gülenists thus separated from MÜSIAD, and TUSKON became a transnational organisational umbrella under which the businesses affiliated with the Gülen Movement came together for regular trade summits and networking (Hendrick 2013).

\subsection{Commitment and Affiliation}

It is impossible to say precisely how many individuals are, or have been, involved in the Gülen Movement, although an extremely approximate estimation might put the number of close affiliates of Gülen in Turkey somewhere between 500 ,ooo and 2 million people in the pre-2016 era. This ambiguity is partly because there are no official criteria for belonging; there are no initiation rites and no clear membership status. It is also partly because individuals may be involved in different capacities and with greatly differing degrees of commitment. The movement is characterised by a multi-tiered nexus of engagement with three degrees of involvement. At the heart of the movement is a group who are dedicated and loyal followers of Gülen, some of whom may reside with him and receive religious instruction on his ranch in Pennsylvania, but the majority of whom live elsewhere. These individuals are committed disciples and keen consumers of Gülen's teachings either through personal contact or from a distance through print and digital media. They usually work or study in a Gülenist institution of some kind and are fully dedicated in every aspect of their lives to the furtherance of the movement's vision. These individuals display Muslim piety through their lifestyle, personal conduct and dress. Women adopt the modest, tesettür style of clothing that is favoured by conservative, mainly urban women across Turkey, and men often favour smart suits 
and ties. Inter-personal conduct is regulated by strict codes of Islamic morality and contact with the opposite sex is usually limited to verbal greetings and minimal interaction.

Individuals within this core group of movement affiliates express a strong commitment to the principle of dialogue and are consequently generally very open to engagement and conversation with outsiders. The public persona that is projected is extremely affable and helpful. The values of tolerance, hospitality and hard work which are lauded in the work of Gülen are physically embodied by this core group, who strive to apply those teachings on a practical level in their daily lives. The motivation for living in this way is described by Zehra, ${ }^{5}$ a committed follower of Gülen who was a teacher at a (now closed) Gülen school in Turkey in 2013:

You're not only Muslim when you're praying, you're Muslim when you're living - twenty-four hours a day. That's why I love him (Fethullah Gülen) so much, and that's why I'm working here in this school. Because it's something related to a sociable life, you know? I want to do something for this society. That's why I'm working here.

This core group of committed individuals like Zehra is surrounded in more peripheral roles by a contingent who might be best described as sympathisers (onaylayanlar), who are active yet more casual supporters of the Gülenist vision and the movement's activities. This group includes, significantly, businessmen of a pious disposition who lend critical financial support to the movement's projects. It also includes individuals who might attend, either regularly or sporadically, the events known as sohbet (lit: 'conversation') at which the books and sermons of Fethullah Gülen are studied and expounded by followers in conjunction with the Risale of Said Nursi and the Qurān. ${ }^{6}$

The largest and most peripheral stratum of participation in the broad Gülenist project is occupied by those who consume the products and services offered by Gülenist institutions, and who may or may not be cognisant of the connection of those products and services to the movement. These might include readers and viewers of the various print, digital and visual media channels run by the movement, clients in the banking and insurance sector, patients in Gülen-run medical facilities, and parents of children studying at

5 Not her real name.

6 The sohbet tradition is not unique to the Gülen Movement, but is practiced in many Islamic groups in Turkey and elsewhere. The focus of discussion is usually the Qurān and Sunna of the Prophet Muhammad. See Jassal 2013. 
Gülen schools. Within Turkey, when the GM was still operational there, it is most likely that these consumers were aware to some extent of the Gülenist origins of these products, but outside Turkey it is possible that these parents and consumers have not necessarily been aware of the existence of Fethullah Gülen or such a thing as the Gülen Movement at all.

\section{$5 \quad$ Gülen's Move to the US and Globalisation of the Movement}

Partly as a culmination of domestic political shifts in the 1980s, the 199os saw the rise to power in Turkey of the Islamist Welfare Party (Refah Partisi), the precursor to the AKP, which was in office between 1996 and 1997 under the leadership of Prime Minister Necmettin Erbakan (White 2002). Erbakan and his government left office after a so-called 'postmodern coup' in 1997, which aimed to restore Turkey's constitutionally secular principles to the national order. Gülen had not openly lent his support to the Welfare Party, choosing to retain his distance from the political Islamism of Erbakan's group in much the same way that Nursi had kept his distance from Adnan Menderes and the Democrat Party (Demokrat Partisi) in the 1950s. ${ }^{7}$ However, in the tense atmosphere of the anti-Islamist period which followed the 1997 coup, Gülen was also implicated. He was wanted by the authorities for his involvement in what were perceived as anti-secular activities of his own, and a warrant was issued for his arrest. In 1999, Gülen left Turkey for America. Later on, during the heyday of his unofficial alliance with the AKP government, the charges against him were lifted, yet he chose not to return, always enigmatically citing 'poor health' as his reason for preferring to remain in the US.

The decade following Gülen's move to America witnessed the movement's fuller global expansion, as well as the rapid development of its activities in the USA itself. While Turkey remained central, the movement now managed a sizeable portfolio of interests in the USA including a number of major dialogue platforms (namely, the Rumi Forum in Washington D.C. and the Gülen Institute in Houston) and somewhere in the region of 150 charter schools (Hendrick 2013). Between 2000 and 2013, it also expanded its global activities to an estimated 16o countries all around the world, ranging from Europe (Balcı 2018; Ozzano 2018; van Bruinessen 2014) to South America (Dumovich 2018),

7 The political Islamist ideology of the Welfare Party inspired the development of Milli Görüş, a major Turkish diaspora movement quite distinctive from the global Gülen Movement, espousing a political vision for the future of Islam. The key founding members of the AKP were all previously members of the Welfare Party. 
and Sub-Saharan Africa to South East Asia (Dohrn 2014; Saleem and Osman 2019) where it has run a global network of schools, medical facilities, dialogue platforms and business interests.

Since the coup attempt, elaborated on below, the Turkish government has made sustained attempts to force the closure of GM schools and businesses overseas. For the most part, it has been successful in those countries where Turkey wields cultural and/or economic influence (Azerbaijan was amongst the first to close all GM institutions, some of which have subsequently been taken over by the state), but generally less so elsewhere. The GM has mostly retained its freedom to operate in Western nations, which tend to be immune to Erdoğan's appeals for the GM to be punished and expelled.

The context for the GM's period of prosperity and wealth accumulation in the early 2000 s was an unofficial alliance that it established with the AKP government. Following its landslide electoral victory in 2002, the AKP was able to command a single-party majority in the Turkish Parliament for the first time since 1983. Gülen commanded his followers to vote for the AKP, but their numbers were not enough to significantly impact its electoral successes: the GM is an elitist rather than a grassroots organisation, and its primary source of usefulness to the AKP did not rest in the numbers of voters it attracted. Rather, sharing a common commitment to religious conservatism and a desire to weaken the power of the Kemalist establishment, the GM was an essential ally to the government because it commanded a loyal support base scattered throughout the civil service, the police force and the judiciary. The AKP was therefore able to circumvent the separation of powers between the legislature, the executive and the judiciary by calling on Gülenist allies for help. The clearest example of this was in the Ergenekon, Balyoz and Poyrazköy trials beginning in 2008, when Gülenist prosecutors brought falsified charges against over a hundred key secularists and government detractors.

While the falsification of evidence which underpinned these trials is now acknowledged, it was, remarkably, almost entirely unquestioned at the time (an exception being Jenkins 20o9). The trials commanded broad support, not only from a conservative religious constituency but also from the nation's secular intellectuals, most of whom endorsed the narrative that calling the army generals to account, and reining in the political power of the military, paved the way for a new era of fuller democratisation in Turkey. Despite the dubious validity of the evidence presented, a popular narrative argued that by seeking 
to downgrade the guardianship of the armed forces over the secular state, Turkey was coming into line with European Union requirements surrounding freedom of expression and the conditions associated with liberal democracy. In turn, there was much support in Europe and the US for these moves to apparently liberalise the Turkish political landscape. A Brookings Institution briefing from April 2012, for example, declared that "the AKP heralds democracy," and described its potential (widely discussed at the time) to serve as a successful model to Arab nations in the wake of the regional uprisings (Taşpınar 2012).

During the AKP's second term in office, tensions began to appear in public between Prime Minister Erdoğan and Fethullah Gülen. These tensions did not manifest themselves in the parliamentary context, for there were only very few Gülenists in cabinet positions. Rather, as tensions rose, they became apparent in broader power-struggles, as the movement exerted its considerable influence within the police force and the judiciary.

One of the earliest sources of conflict between the two men, and the subject of their first public disagreement, was in the realm of international affairs and concerned Turkey's relationship with Israel. Throughout the twentieth century, Turkey had been a rare regional ally of Israel and relations between the two countries had been generally strong. Since Prime Minister Erdoğan's rise to power this relationship has deteriorated severely. Various diplomatic spats between the two countries have escalated rapidly, fuelled in part by an ideologically-driven anti-Israeli rhetoric from the Prime Minister himself. The failure of diplomatic relations between Turkey and Israel has been accompanied by a surge in anti-Israeli sentiment in the general public. When Erdoğan publically stormed out of a debate on Gaza with Israeli President Shimon Peres at the Davos World Economic Forum in 2009, he was greeted as a returning hero on his arrival in Turkey, with cheering crowds waiting for him at the airport.

Gülen's stance on Israel is markedly different from Erdoğan's, and is shaped by his support for American neo-liberal values. The Prime Minister's public rhetoric against Israel sat uneasily with Gülen, and while he did not speak out after the Davos affair he did intervene in the Mavi Marmara incident of the following year. This incident, in which nine Turkish activists on a humanitarian flotilla were killed at sea by Israeli soldiers in their attempt to break the blockade on Gaza, led to the expulsion of the Israeli ambassador from Ankara and the suspension of diplomatic relations between the two countries. Gülen spoke out publically, suggesting that the confrontational approach of the activists had been misplaced and that the pursuit of a diplomatic path would have been preferable, both before the crisis and in its aftermath ("Fethullah Gülen Mavi Marmara Baskını Hakkında Görüşleri”, 2013). His position brought him into direct conflict with the Prime Minister and 
with public opinion more widely, and although there was only muted public response to an interview that he gave, it was a sign of further trouble to come.

The major deterioration in AKP-Gülenist relations came nearly two years later in February 2012, when Gülenist prosecuters sought the arrrest of Hakan Fidan, the head of Turkey's National Intelligence Organisation (Milli İstihbarat Teşkilatı, MIT) and a close personal ally of Erdoğan. Fidan was engaged at the time in secret, high level talks with Abdullah Öcalan, the highly-controversial leader of the Kurdish PKK who is serving a life prison sentence. The Kurdish issue is a subject on which the movement had differed ideologically from the AKP: being strongly informed by Turkish nationalist ideology, the movement was not a keen supporter of the government's tentative rapprochement with Kurdish separatists. Erdoğan was able to stop Fidan's arrest by issuing emergency legislation the following day, but the movement's attack on such a highlevel AKP ally was perceived as a declaration of open warfare.

It was not long until the government hit back. In October of the same year, the Prime Minister announced his intention to forcibly close down the nation's dershane network, an area in which followers of Gülen were heavily invested ("Dersaneler Kapanacak" 2012). According to this new plan, dershanes across the country were to be turned into private schools, ostensibly because the government no longer wished to tolerate a parallel system of education provision. The inefficiencies and inequalities of the dershane system were not in doubt, but the sudden anouncement of their impending closure came as a shock to many. The Gülen Movement was amongst the foremost providers of dershane education in Turkey; large national franchises such as FEM, as well as innumerable smaller operations, provided a valuable source of income to the movement, and also acted as its primary recruitment ground. In threatening to close them down, the AKP government knew that it was targetting one of the major arteries of the movement's social and economic power. Gülen recognised the severity of the threat and offered to voluntarily turn the movement's dershanes over to state control, but the offer was rejected.

Against this backdrop of mounting tension, relations between the two groups failed irretrievably in 2013. In May and June of that year, the Gezi Park riots dominated the national news. Violent protests spread from a park in central Istanbul to Ankara, Izmir and many other major cities across Turkey. The riots began as a small-scale, environmental protest but soon became a national movement focused on opposition to Prime Minister Erdoğan. Erdoğan responded by ordering a harsh police crackdown, which resulted in multiple deaths and many serious injuries. It also triggered widespread criticism of his handling of the crisis in the international media (Letsch 2013).

The protesters were drawn from a wide range of social and religious backgrounds, including a group calling itself 'Anti-Capitalist Muslims', but were 
dominated by individuals of a secular-leaning, educated and urban background. These are not the people of Gülen's core constituency, and he voiced his criticism of the protesters, declaring that their actions were indicative of 'a generation of moral and spiritual decay' ("323.Nağme” 2013). Gülen was also, however, openly critical of the AKP's response to the situation and publically condemned its excessive use of force to quash the riots. He was not alone in voicing criticism of Erdoğan's heavy-handed approach-indeed, various senior members of the AKP did as well, namely incumbent president Abdullah Gül and deputy Prime Minister Bülent Arınç. Nonetheless, Gülen's public criticism of the then-Prime Minister did nothing to improve already deteriortating relations between the two men.

Escalation of the mounting power-struggle between Gülen and his followers and Erdoğan's AKP came with the corruption scandal that erupted on 17 December 2013. The Gülenists played their best hand in revealing material that appeared to indicate endemic corruption within the AKP and embezzlement of public funds on a shocking scale. It was a bold move. The recordings that were leaked a few months later on 24 February 2014, purporting to show the Prime Minister and his son conspiring to secrete away huge sums of money, were their strongest blow. The veracity of the recordings was never clearly established, although many, including opposition politicians, believed that they were genuine (Nakhoul and Tattersall 2014). What is certain, however, is that the Gülenists obtained them through illegal means by the sustained wire-tapping of encrypted government telephone lines, and their intention was clearly to fatally destabalise Erdoğan's government. Nevertheless, while Erdoğan suffered some losses, he and his party still secured a majority in both local and presidential elections the following year: the Gülenists' plot had failed.

\subsection{The Coup Attempt of 15 July 2016 and its Aftermath}

Two and a half years later, amidst on-going hostilities between Erdoğan and the GM, the country was shaken to the core by a military coup attempt. A bloody and chaotic night saw aircraft from a rebel faction within the armed forces attack, amongst other targets, the Turkish intelligence headquarters and the parliament in Ankara, and an embattled President Erdoğan addressing the nation via the 'Facetime' app on his mobile phone, inviting his supporters to come out onto the streets to resist the military takeover-something which hundreds of them duly did (Nakhoul and Tattersall 2014). The frenzied scenes of pro-government civilians overrunning military tanks on the Bosphorus Bridge (since renamed 15 Temmuz Şehitler Köprüsü, '15 July Martyrs' Bridge') became emblematic of the night, and the triumph of Erdoğan over the coup plotters. 
Erdoğan made it clear immediately, during this address in the early hours of the morning and at the height of the crisis, that he held Fethullah Gülen and his followers to blame for the coup attempt, and for attempting to violently dismantle Turkey's democratic tradition. Over the course of the night, the government and its supporters repudiated the coup and regained control, but not without the loss of almost 300 lives. Subsequently, close to 150,00o individuals were either arrested or suspended from their duties across an extremely wide section of Turkish civil society, and a state of emergency was instigated, which was to continue for two years, until July 2018. Turkey continues to formally request the extradition of Gülen by the US authorities amid suggestions that the death penalty could be re-introduced as punishment for the plotters. To date, this extradition request has not been granted.

The coup attempt signalled a catastrophic end for the GM in Turkey as well as a catalyst for Erdoğan to consolidate his power, capitalising on a paranoid narrative that posits the president as defender of the nation in the face of threats to its security from within and without. Following a public referendum in 2017, Turkey will change from a parliamentary to presidential system with Erdoğan at the helm. The separation of powers has been almost entirely eroded, and executive power henceforth resides exclusively in the person of the president. Deteriorations in the economy in recent years have impacted somewhat on Erdoğan's popularity, a fact that was reflected in the local elections of April 2019, in which the opposition unexpectedly took control of the Ankara as well as Istanbul municipalities for the first time in over 25 years. ${ }^{8}$ While this turn away from the AKP at a local level in Turkey's two major cities is significant, general elections are not scheduled until 2023 and it is unlikely that anything will loosen Erdoğan's grip on power at a national level in the near future. The ramifications for the GM are severe: the government in Turkey continues to seek out Gülenist sympathisers, real or imagined, for punishment.

\section{7}

\section{Conclusion}

The GM is now tasked with counting its considerable losses, adapting to its position in exile, and forging a new future for itself in the face of extreme hostility from the Turkish government. It has lost a considerable amount of financial wealth through the confiscations of the Turkish state since 2016, and there have been far fewer instances of the lavishly funded public engagement

8 At the time of writing (April 2019), the outcome of the Istanbul ballot was being contested by the government. 
activities that once characterised the global GM. ${ }^{9}$ Many followers of Gülen are imprisoned in Turkey, and those who managed to flee the country are dependent on on-going asylum applications elsewhere. In the midst of these seismic changes, the internal integrity of the movement has suffered a blow: for the first time, GM insiders have spoken out critically about Fethullah Gülen and his leadership. Such criticisms had previously only been voiced by those who had left the GM, and they are indication of the potential for damaging internal divisions that could change the future course of the movement.

In sum, the post-coup GM is in many ways a fractured and diminished organisation. Yet at the same time, entirely typically of the movement, it appears to be adapting to these new circumstances and finding a way to capitalise on them. Adaptation to local circumstance and opportunity is one of the hallmarks of the GM. While the core activities of the movement have been the same in every location that it has been present in, the movement has nonetheless always endeavored to engage with the particular strategic opportunities of each place (Tee 2016: 119-139). In the West, and in the US especially, the strategic focus of the GM has always been public relations. It has run schools as well, ${ }^{10}$ but an equally important focus of its activities in the US and UK has been the establishment of debating and public engagement organisations such as Rumi Forum in Washington DC and the Dialogue Society in London. In the post-coup era, its investment in building up a credible presence for itself in Western nations as a Muslim voice of dialogue and moderation is paying dividends. The GM retains a lobbying presence in DC and London, as well as in Brussels, and its fight back against President Erdoğan is taking place partly through English-language publications of its PR organisations. ${ }^{11}$ Erdoğan has already lost almost all the international political support that he commanded in the first two terms of his office as PM, and is now regarded by western governments as a volatile and dangerous 'strongman' leader. The GM's ability

9 For example, the GM funded and organised a number of large conferences in the UK and US in the first decade of this century, all of which were heavily subsidised and generously catered for. At a local level as well, spending seems to be diminished (Tee 2018).

10 In the UK, the GM has only ever had one school, North London Grammar school in Hendon (established 2014), previously Wisdom School in Haringey (established 2006). Elsewhere in the West, and especially in the US where the charter school system suits its ends, the GM's schools have been greater in number.

11 See, for example, the publications of the Centre for Hizmet Studies, particularly an article by Özcan Keleş of London's Dialogue Society, published two months after the coup (Keleş 2016). The article is a compelling but blinkered defense of Gülen and the GM. The GM's publishing houses in the US continue to produce hagiographic materials on Gülen, including most recently Jon Pahl's Fethullah Gülen: A Life of Hizmet (New Jersey: Blue Dome, 2019). 
to communicate in excellent English and to circulate its self-representative accounts of the war with Erdoğan in the centers of western political power is very clearly advantageous.

The academic literature since 2016 has of course focused on the coup and its aftermath. The field has moved on rapidly in that time, and there is now a body of critical literature that is making inroads into analyzing the G M through sociological, anthropological, and political science lenses. This literature is well aware of the GM's complexities and shows none of the 'enchanted' tone of some of the work that came before. Simon Watmough and Ahmet Erdi Öztürk's article of 2018, which prefaced a special journal issue on the GM in post-coup exile, is an incisive and empirically informed analysis of the GM that focuses on its pursuit of power. This analytical approach is shared by Hakan Yavuz and Bayram Balcı, two long-time scholars of the GM, whose edited collection of 2018 analyses the movement's involvement in the coup and its aftermath. A broad scholarly consensus is emerging which sees the GM neither as the pacifist, dialogical voice for modern Islam that it presents itself as in the West, not as the sharía-minded terrorist or revolutionary movement that many see it as in Turkey, but rather as an organisation inspired by religion but in pursuit of worldly power, wealth and influence. The next chapter of the GM's life has yet to be written, but it is highly likely that its voracious appetite for such power, along with its successful negotiation of an amenable, post-9/11 political landscape in the West, will mean that, in spite of Erdoğan's best efforts, we are far from seeing the end of it yet.

\section{References}

“323.Nağme: Taksim Gezi Parkı Hadiseleri ve Problemlerin Temeli." 2013. Herkul, 6 June. At http://www.herkul.org/herkul-nagme/323-nagme-taksim-gezi-parki-hadiseleri -ve-problemlerin-temeli/. Accessed 13/04/2019.

Abu-Rabi, I.M. ed. 2003. Islam at the Crossroads: On the Life and Thought of Bediüzzaman Said Nursi. Albany: State University of New York Press.

Abu-Rabi, I.M. 2008. Spiritual Dimensions of Bediüzzaman Said Nursi's Risale-i Nur. Albany: State University of New York Press.

Agai, B. 2002. "Fethullah Gülen and his Movement's Islamic Ethic of Education." Critique: Critical Middle Eastern Studies. 11:1, 27-47.

"Dersaneler Kapanacak." 2012. Yeni Asir, 7 October. At https://www.yeniasir.com.tr/ politika/2012/10/o7/dershaneler-kapanacak. Accessed 17/04/2019.

Dohrn, K. 2014. "Translocal Ethics: Hizmet Teachers and the Formation of Güleninspired Schools in Urban Tanzania." Sociology of Islam. 1, 233-256. 
Dumovich, L. 2018. "Pious Creativity: Negotiating Hizmet in South America After July 2016." Politics, Religion and Ideology. 19:1, 81-94.

Ebaugh, H.R. 2010. The Gülen Movement: A Sociological Analysis of a Civic Movement Rooted in Moderate Islam. New York: Springer.

Esen, B. and Ş. Gümüşçü. 2017. "Turkey: How the Coup Failed." Journal of Democracy. 28:1, 59-73.

"Fethullah Gülen Mavi Marmara Baskını Hakkinda Görüşleri." YouTube, 29 November, 2013. At https://www.youtube.com/watch?v=th4OF_2ddBo. Accessed 13/o4/2019.

Gülen, M.F. 2004. Key Concepts in the Practice of Șüfism: Emerald Hills of the Heart. Vol. 2. New Jersey: The Light.

Gülen, M.F. 20o6. Toward a Global Civilisation of Love and Tolerance. Somerset, NJ: The Light, Inc. 2006.

Gülen, M.F. 2011. Key Concepts in the Practice of Șüfism: Emerald Hills of the Heart, Vols 1-4. Clifton, NJ: Tughra Books.

Hendrick, J.D. 2013. Gülen: The Ambiguous Politics of Market Islam in Turkey and in the World. New York: New York University Press.

Hendrick, J.D. 2009. "Globalization, Islamic activism and passive revolution in Turkey: the case of Fethullah Gülen." Journal of Power. 2:3, 343-368.

Jassal, S.T. 2013. "The Sohbet: Talking Islam in Turkey." Sociology of Islam. 1, 188-208.

Jenkins, G. 20o9. “Between Fact andFantasy:Turkey'sErgenekon Investigation.” SilkRoad Paper. At http://www.silkroadstudies.org/resources/pdf/SilkRoadPapers/20o9_o8 _SRP_Jenkins_Turkey-Ergenekon.pdf. Accessed 11/o4/2019.

Keleş, Ö. 2016. "Questions we dare not ask: Gülen and the coup." Centre for Hizmet Studies, 9 September. At https://www.hizmetstudies.org/commentary/questions -we-dare-not-ask-gulen-and-the-coup/. Accessed 17/04/2019.

Lesage, D. 2019. "Turkey and the Gülen Movement: The Geopolitical Dimension." Unpublished conference paper, ISA AC Toronto.

Letsch, C. 2013. "Turkey protests spread after violence in Istanbul over park demolition." The Guardian, 1 June. At http://www.theguardian.com/world/2013/may/31/ istanbul-protesters-violent-clashes-police. Accessed 13/04/2019.

Lord, C. 2018. Religious Politics in Turkey: From the Birth of the Republic to the AKP. Cambridge: Cambridge University Press.

Mango, A. 2004. The Turks Today. London: John Murray.

Mardin, Ş. 1989. Religion and Social Change in Modern Turkey: The Case of Bediüzzaman Said Nursi. Albany: State University of New York Press.

Mercan, F. 2008. Fethullah Gülen. Istanbul: Doğan.

Nakhoul, S. and N. Tattersall. 2014. "Turkish PM says takes of talk with son a fabrication." Reuters, 25 February. At http://www.reuters.com/article/2014/o2/25/us-turkey -erdogan-idUSBREA1N1ZX2O14O225. Accessed 13/04/2019. 
Özdalga, E. 2007. “Worldly asceticism in Islamic casting: Fethullah Gülen's inspired piety and activism." Critique: Critical Middle Eastern Studies. 9:17, 83-104.

Pandya, S. and N. Gallagher eds. 2012. The Gülen Hizmet Movement and its Transnational Activities: case studies of altruistic activism in contemporary Islam. Boca Raton, FL: BrownWalker Press.

Taş, H. 2017. "A History of Turkey's AKP-Gülen Conflict." Mediterranean Politics. 23:3, $395^{-402 .}$

Taşpınar, Ö. 2012. “Turkey: The New Model?” Brookings. 25 April. At http://www .brookings.edu/research/papers/2012/04/24-turkey-new-model-taspinar. Accessed 11/04/2019.

Tee, C. 2016. The Gülen Movement in Turkey: The Politics of Islam and Modernity. London: I.B. Tauris.

Tee, C. 2018. "The Gülen Movement in London and the Politics of Public Engagement: Producing 'Good Islam' Before and After 15 July.” Politics, Religion and Ideology. 19:1, 109-122.

Tee, C. and D. Shankland. 2014."Said Nursi's Notion of 'Sacred Science': Its function and application in Hizmet high school education." Sociology of Islam. 1:3-4.

Turam, B. 2003. "National Loyalties and International Undertakings: The case of the Gülen community in Kazakhstan.” In M. Hakan Yavuz and J.L. Esposito eds, Turkish Islam and the Secular State: The Gülen Movement. New York: Syracuse University Press, $184-207$.

Turner, C. 2010. "The Six-Sided Vision of Said Nursi: Towards a Spiritual Architecture of the Risale-i Nur." Islam and Christian-Muslim Relations. 19:1, 53-71.

Ünal, A. and A. Williams. 1999. Advocate of Dialogue: Fethullah Gülen. Fairfax VA: The Fountain.

Vahide, S.. 2005. Islam in Modern Turkey: An Intellectual Biography of Bediüzzaman Said Nursi. Albany: State University of New York Press.

van Bruinessen, M. 2014. "The Netherlands and the Gülen Movement." Sociology of Islam. 1, $165^{-187}$.

Vicini, F. 2013. "Pedagogies of Affection: The Role of Exemplariness and Emulation in Learning Processes-Extracurricular Islamic Education in the Fethullah Gülen Community in Istanbul." Anthropology and Education Quarterly. 44:4, 381-398.

Watmough, S.P. and A.E. Özturk. 2018. "From 'Diaspora by Design' to Transnational Political Exile: The Gülen Movement in Transition." Politics, Religion and Ideology. 19:1, 33-52.

Weismann, I. 2007. The Naqshbandiyya: Orthodoxy and Activism in a Worldwide Șūfi Tradition. Abingdon: Routledge.

Weller, P. and I. Yilmaz eds. 2012. European Muslims, Civility and Public Life: Perspectives on and from the Gülen Movement. New York and London: Continuum. 
White, J.B. 2002. Islamist Mobilisation in Turkey: A Study in Vernacular Politics. Seattle: University of Washington Press.

Yavuz, M.H. 2013. Toward an Islamic Enlightenment: The Gülen Movement. New York: Oxford University Press.

Yavuz, M.H. and B. Balcı eds. 2018. Turkey's July 15th Coup: What Happened and Why. Salt Lake City: University of Utah Press.

Yavuz, M.H. and J.L. Esposito eds. 2003. Turkish Islam and the Secular State: The Gülen Movement. New York: Syracuse University Press.

Zarakol, A. 2016. "The Failed Coup in Turkey: What We Know So Far." PONARS Eurasia Policy Memo. 433.

Zürcher, E. 2004. Turkey: A Modern History. London: I.B. Tauris. 